\title{
REVALORIZATION OF EXISTING TAILING DUMPS IN SERBIA: BOR AND RUDNIK CASE STUDIES
}

\author{
Boris Vakanjac*, \\ Lidija Amidžić, \\ Tanita Đumić \\ Singidunum University \\ Belgrade Serbia
}

\begin{abstract}
:
In general, there are two geological entities of interest for the study of the historic past and current research of deposits of metallic mineral resources in Serbia. The first is the Timok magmatic complex where there are mineral parageneses and associations developed from low sulfidation to high sulfidation systems. These deposits are of the upper Cretaceous age. The second complex is composed of Oligocene/Miocene deposits, whose direction is generally NNE-SSE. They mainly contain lead and zinc sediments with accompanying useful components. In both metallogenic zones, there are numerous tailing dumps that carry both useful components and environmental pollutants. Two things are highlighted with regard to recycling of tailings. The first, tailing dumps threaten the environment for as long as they exist. The second, useful trace elements remaining after ore extraction with past and present technologies can be commercialized and the toxic or unusable components disposed in an environmentally-friendly manner.
\end{abstract}

Correspondence:

Boris Vakanjac

e-mail:
Keywords:

ore deposit, tailing dumps, revalorization.

\section{INTRODUCTION}

Sulfidic polymetallic ores originate from complex, generally hydrothermal processes. Today, the finding of new ore bodies requires considerable funding and teams of experts. Concentrations that attract interest are decreasing. Ore deposits contain appreciable amounts of gold, trace elements and rare earths, which are also being extracted. However, due to the inability to fully valorize useful components, some remain in tailing dumps. Given that mineral resources are non-renewable, tailing dumps will certainly begin to be valued in the future, especially those of non-ferrous metals but also other minerals. A detailed study of this subject matter would require considerable funding and human resources, but the end result would be an enormous amount of information and new ore reserves. The paper discusses only a small part of this vast area of research. The focus will be generally on iron sulfides and two characteristic representatives in Serbia: the copper mine of the Bor Mining Basin and the Rudnik mine (on Mt. Rudnik). The copper and gold deposits in the Bor Mining Basin are located in eastern Serbia, in hydrothermally altered Late Cretaceous andesites. The polymetallic deposits at the Rudnik mine are near the city of Gornji Milanovac and the host rocks are Cretaceous composites of sedimentary rock with intrusions of largely Oligocene quartz latite, associated with hydrothermal solutions (Stojanović et al. 2016). 


\section{SETTINGS IN WHICH SULFIDIC POLYMETALLIC DEPOSITS ARE FORMED}

The mineral composition of igneous rocks - andesites, dacites and quartz latites - generally includes: feldspars, amphiboles (hornblende), pyroxene, biotite, quartz, and the like. These rocks and their pyroclastic varieties (tuffs) are frequent bearers of sulfidic polymetallic ores. The primary minerals were transformed/altered during the ore formation process. Ore-bearing hydrothermal solutions were generally acidic in nature. Hornblende and biotite were transformed into chlorite and feldspars into sericite and mineral clay, with some fine-grained quartz. Porphyritic quartz in dacites was resistant and did not tolerate chemical alteration. Ore minerals were deposited in voids, fissures and fractures, or metasomatically in spaces where iron leached from dark rock minerals. This is typical of so-called porphyritic copper deposits (Byron et al. 2008).

\section{TRANSPORT OF METALS IN HYDROTHERMAL SOLUTIONS}

As is well known, alkalis and metals existed in hydrothermal solutions as chlorides or complex ions (e.g. $\mathrm{Cu}$, $\mathrm{Zn}, \mathrm{Pb}, \mathrm{As}, \mathrm{Ag}, \mathrm{Tl}, \mathrm{Ge}, \mathrm{Ga}, \mathrm{Se}, \mathrm{Sn}, \mathrm{Hg}$ etc.). These compounds constituted a minor portion of the hydrothermal solutions, whose composition was: $\mathrm{H}_{2} \mathrm{O}$, high concentrations of $\mathrm{NaCl}$, varying concentrations of $\mathrm{CO}_{2}$, and some carbonate, bicarbonate and sulfide. Metal concentrations range from $1 / 100$ to $1 / 1000 \mathrm{mg} / \mathrm{l}$. Hydrothermal solutions evolved and their pressure, temperature, $\mathrm{Eh}$ and $\mathrm{pH}$ changed. The solutions that affected rocks were hot and aggressive. The temperature of the solution is assumed to have been between 450 and $100^{\circ} \mathrm{C}$. At such temperatures, the concentrations of hydrogen ions were high and the $\mathrm{pH}$ level of the solution 5.5 (at times even less than 3.5). These hydrothermal solutions always reacted with their environment, on order to become neutralized. Given that the anion concentration was high, complex compounds were created and they facilitated transport of metal salts of low solubility. This enabled a dynamic equilibrium between the ions in solution, newly created complex ions and minerals (Seward, Williams-Jones \& Migdisov, 2013).

\section{Iron sulfides pyrrhotite and pyrite}

Some of the sulfide minerals often developed in base and precious metals deposits are pyrite (Fe sulfide), pyrrhotite (Fe sulfide), chalcopyrite ( $\mathrm{Cu}$ sulfide with $\mathrm{Fe}$ ), galenite ( $\mathrm{Pb}$ sulfide), sphalerite ( $\mathrm{Zn}$ sulfide), arsenopyrite (As sulfide with $\mathrm{Fe}$ ), bornite ( $\mathrm{Cu}$ sulfide with $\mathrm{Fe}$ ), enargite (Cu sulfide with $\mathrm{As}$ ), chalcosine ( $\mathrm{Cu}$ sulfide), covellite $(\mathrm{Cu}$ sulfide), and the like.
The iron sulfides pyrite and pyrrhotite are almost always found in sulphide ore deposits. Pyrrhotite has more Fe (62.33\%) (http://webmineral.com/data/Pyrrhotite. shtml\#.XYp1Si4zbmg) and pyrite less (46.55\%) (http:// webmineral.com/data/Pyrite.shtml\#.XYp1Bi4zbmg). Pyrite and pyrrhotite are found in either large or small quantities, or they are totally lacking in certain parts of the ore deposits. The problem is that they have been considered unusable and the Fe from them was not extracted. One of the important properties of pyrite and pyrrhotite is that they can integrate with other minerals, elements $(\mathrm{Au}, \mathrm{Cu}, \mathrm{Co}, \mathrm{Ni}$, etc.), as well as rare and diffuse components. The pyrrhotite content of different ore deposits is not the same. Its theoretical variety is called troilite. The formula is $\mathrm{Fe}_{(1-\mathrm{x})} \mathrm{S}$, where $\mathrm{x}$ is from 0 to 0.2 . The proportion (formula) of Fe in pyrrhotite can vary from 7 to 11, and of $\mathrm{S}$ from 8 to 12. Apart from troilite, pyrrhotites are magnetic and of a pinkish metallic color. Pyrite has a stable formula - $\mathrm{FeS}_{2}$. It can be idiomorphic (euhedral), in the form of fine-looking cubes. The color is metallic yellow. It could also have been created exogenously in coal deposits https://www.sciencedirect.com/topics/chemistry/pyrite.

One of the characteristics of the origin of sulfides from hydrothermal solutions is instantaneous crystallization in gels. As high-temperature hydrothermal solutions, in the form of water vapors and other gasses with complex ion metals, reached a void created by tectonics or rock alteration, the pressure and temperature dropped suddenly and a sulfidic mass was deposited from the solution as a eutectic mixture. Sulfide crystallization centers were formed in the eutectic mixture relatively quickly. Since various metals and sulfur were present, typical gel-like textures - sulfide aggregates - were formed, for example of pyrite and sphalerite, pyrite and galenite, pyrrhotite and chalcopyrite, etc. These aggregates also exist on a molecular level. Hence, chemical analyses of ores report certain quantities but the valorization of useful components in ores results in "impoverishment". Iron sulfides are disposed of on tailing dumps. Ore processing by different methods (grinding, floating, roasting...) concentrates and releases useful components. This includes Fe sulfides, generally removed from, for example, sphalerites or chalcopyrites, but a part of the useful components remain in the iron sulfides and, as previously stated, end up in tailing dumps (Björn Öhlander, Terrence Chatwin \& Lena Alakangas 2012).

Exposed to atmospheric conditions, Fe sulfides and residual constituents weather over time, creating a weak sulfuric acid that is leached into the environment. Fe creates hydroxides - limonite. The said micro concentrations of useful and/or toxic components partially remain in the system, and the remainder, as soluble compounds, also ends up in the environment. Such fine aggregates of pyrite and, for example, enargite or pyrrhotite and arsenopyrite, weather and arsenic (or lead) is released, which can also reach the environment. 
Residual copper from $\mathrm{Cu}$ bearing sulphides create malachite and azurite stains in environment, and this is sign of copper presence in particular area of interest (Vakanjac, 2000).

\section{MICROSCOPIC ANALYSES OF PRITE FROM THE MAJDANPEK MINE AND PYRRHOTITE FROM THE RUDNIK MINE}

\section{Characteristics of pyrite from the Bor Mining Basin}

Pyrite is generally found in two types of ore: (i) with chalcopyrite and bornite and (ii) massively with covellite and chalcosine.

Impregnational-metasomatic-porphyry type of ore: The marketable copper minerals of this type are chalcopyrite and bornite. Pyrites occur as grainy impregnational mineralizations, always on positions of altered femic minerals. Grain sizes vary and the grains can be round, with impregnations of pyrrhotite, chalcopyrite and bornite. At times they adhere to the shape for a former femic mineral, which they impregnate into a group of tiny xenoblasts. Another relatively frequent type of deposition is aggregates with chalcopyrite. These aggregates were formed simultaneously. They are composed of integrated pyrites and chalcopyrites. The grain sizes range from several to rarely $300 \mu \mathrm{m}$. Large grains sometimes built complex aggregates with fragments of gangue and rutile. Also, magnetite can be found in contact with these aggregates. Pyrite aggregates with magnetite and hematite-musketovite have been observed as well. Pyrite veinlets with or without chalcopyrite are the locally dominant type of mineralization, developed in fissures of rather hydrothermally altered settings. The width of the veinlets ranges from several hundred $\mu \mathrm{m}$ to $1 \mathrm{~mm}$. They are generally surrounded by high concentrations of pyrite impregnations with chalcopyrite. Specifically, in the Tilva Roš ore body, the nature of pyrite changes; the amounts of pyrite with impregnations of bornite and chalcopyrite, and aggregates of pyrite with chalcopyrite, decrease. Pyrite grains are locally cemented with covellite (Vakanjac, 2000).

Massive type of ore with covellite and chalcocite: The marketable copper minerals of this type are covellite, chalcocite and enargite. Pyrite in association with these minerals most often has an anhedral-gel structure, partly recrystallized and cataclazed. It occurs in concentrations of irregular shape and small nests in the ore mass. It is rarely idiomorphic, up to several tens of $\mu \mathrm{m}$ in size, developed in both the host rock and fissure and fracture systems. It has been detected in all ore varieties typical of this type of mineral association (Vakanjac, 2000).

\section{Characteristics of pyrrhotite from the Rudnik mine}

Pyrrhotite is the most widespread mineral at the Rudnik mine. It has built aggregates with all other sulfides. The other sulfides are often impregnated in pyrrhotite as fine grains. Macroscopically, they are composed of pyrrhotite and some gangue. A binocular magnifier showed that a sample contained pyrrhotite as the dominant component, combined with a small quantity of gangue in a relatively consistent mixture. Among the gangue minerals, the lighter gel forms reacted with $\mathrm{HCl}$. The sample was highly magnetic. The pyrrhotite concentrations were anhedral. The sample was fissured, locally cataclazed, and grains of quartz could be discerned. Exceptionally, the separation of pentlandite was noted, as an independent grain in the pyrrhotite mass. Chalcopyrite and sphalerite were generally developed on the edges of pyrrhotite concentrations and along fractures. Chalcopyrite was deposited in the form of allotriomorphic concentrations, generally as an aggregate with pyrrhotite and rarely sphalerite, as well as chalcopyrite drops in sphalerite. Sphalerite, like chalcopyrite, was deposited in the form of inconsistent concentrations that impregnated gangue minerals and quartz grains (Arsenijević, 1971).

\section{TESTING OF TRACE ELEMENT DISTRIBUTIONS}

Trace element distributions in the minerals of sulfide ore deposits have been tested for many years. In general, two approaches were followed: (i) spectral analysis, and (ii) electron microanalysis (wavelength detection of X-ray spectra). Usually tested were composites and monomineral fractions. The monomineral fractions were generally pyrite, pyrrhotite, chalcopyrite, sphalerite, bornite, enargite, covellite, sulfosalts, native gold, galenite, molybdenite, magnetite, and rutile. The assays looked for and generally detected the following elements: $\mathrm{V}, \mathrm{Mn}, \mathrm{Ni}, \mathrm{Cr}$, $\mathrm{Sn}, \mathrm{Sb}, \mathrm{Ag}, \mathrm{Au}, \mathrm{Ga}, \mathrm{Ge}, \mathrm{Re}, \mathrm{Sr}, \mathrm{Bi}, \mathrm{Se}$, and Te. In addition, $\mathrm{Fe}, \mathrm{Cu}, \mathrm{Zn}, \mathrm{Ti}, \mathrm{Pb}, \mathrm{As}$ and $\mathrm{S}$ were sometimes included in the trace elements, but it should be kept in mind that they built the main ore minerals in the study areas, so their presence in the form of trace elements as well is to be expected. The above two test methods have certain limiting factors. In the case of spectral analyses of monomineral fractions, the authors of this paper are certain that they were not fully monomineral for the simple reason that in the two study areas there are either very small grains and aggregates (in metasomatic deposits) or complex forms to the micron level of coalescence, for example of sphalerite with pyrite/pyrrhotite/chalcopyrite, or enargite with pyrite and pyrrhotite with arsenopyrite. Therefore, there is some reservation about the results of spectral or XRF analyses of monomineral fractions. 
Electron microanalysis was much more accurate in terms of localization. The area targeted by the electron beam was from 1 to 3 micrometers, and the depth of the ball up to 4 micrometers, such that in effect 5 to 10 cubic micrometers of material was analyzed. The tested grains were also profiled, to provide very useful data about the distribution of the element within the grain. Today, assays of this type are performed in accredited laboratories by atomic absorption spectroscopy (AAS) and XRF instruments in the field (Baensch, 2011).

\section{NONMETALLIC MINERALS}

Rock minerals and rock alteration products also end up in the tailing dump. Quartz and clay minerals are dominant. The quartz could be useful theoretically, but the grains are heavily stained by various compounds and locally by aggregates with iron sulfides. As such, recycling of nonmetallic waste rock material using current technologies is unlikely https://www.sosbluewaters.org/EPAamd.

\section{CONSIDERATIONS ABOUT TAILING DUMPS AND CIRCULAR ECONOMY}

Bor is actually of a system several deposits that is exploited by open pits and underground mining methods. It is known that after five years of exploration in 1902 copper mineralization in the form of covellite and chalcocite was found. The financier of the investigations was Georg Weifert. Upon the discovery of the copper deposit, he obtained an exploitation License in 1903 and became the first owner of the minefield. Exploitation begins in 1904, (Simić, 1951), and from then continues today (September 2019), the tailings dumps which are disposed in the Bor area, now occupy an area of about 700 acres.

At the Rudnik Rudnik area, the mine has been exploited since prehistoric times, during ancient times, the Middle Ages, and systematic industrial exploitation began in 1953 and continues to this day http://www.contangorudnik.co.rs/sr/o-kompaniji-2/istorija. So, since 1953, tailings have been deposited in the area of the Rudnik. In size is approx. 40 acres (measured on orthophoto map SASPlanet ESRI ArcGis Imagery) https://bitbucket.org/ sas_team/sas.planet.bin/downloads/.

So there is a large amount of disposed material. As well known, the European Commission deals with the circular economy, there is a lot of material, conclusions, and suggestions available on the Internet https://ec.europa. eu/growth/industry/sustainability/circular-economy_en . Today's civilization is, in a material sense, based essentially on mineral resources. Most of the energy is produced from mineral resources (fossil fuels), the copper is needed for the transmission of electricity, the agriculture is unthinkable without fertilizers, construction is based on cement (made of marl), gravel, sand and steel, the electronics industry requires precious and rare metals. It simply implies that existing tailings dumps have to be in detail explored and re-exploited.

\section{CONCLUSION}

Tailing dumps are located in specially designated areas. Mining and construction methods are applied to explore and prepare the area for the disposal of materials that have no use. Some of the waste disposed of in the past would now be considered ore. Consequently, tailing dumps across the world should be investigated and a special database of their characteristics compiled (elements of interest, classifications, etc.). The material found in a tailing dump is already fragmented to a certain extent and has in some cases been exposed to atmospheric conditions for nearly a century.

Even though it does not deal with tailing dumps specifically, (Liu et al. 2018) considers the distribution of the trace elements from pyrrhotite and pyrite in situ, where in the future these minerals will likely be used in parallel with ore extraction. Today, the iron sulfides deposited in tailing dumps should not be ignored.

Up until relatively recently, not much attention has been paid to the environment. The focus has been on avoiding accidents (tailing spillages, casualties and damage). Leaching during wet periods or wind-aided dispersal of deposols in dry periods was the unavoidable price of mining and the extraction of sulfide ore, as well as other ores.

Over time, "low" concentrations have become increasingly interesting. In order to attempt to revalorize a tailing dump, mining of the primary ore deposits needs to be completed first. While the primary mining is in progress, the tailing dump should be investigated, the material estimated, and the mineral and chemical compositions examined, as well as valorization experiments conducted on useful components of the existing material.

\section{REFERENCES}

1. Arsenijević, M. (1971) Retki i drugi mikroelementi u glavnim sulfidnim mineralima olovo-cinkovog ležišta Rudnik. Zbornik Instituta za geološko-rudarska istraživanja $i$ ispitivanja nukleranih i drugih mineralnih sirovina, strane 90-108.

2. Baensch T. A., (2011) Field Portable XRF for Modern Exploration Programs, Deep Exploration Technologies Commonwealth Research Cooperative (DET CRC). 
3. Byron. R. B., Ayuso, A. R., Wynn, C. J., and Seal R. R., (2008) Preliminary Model of Copper Deposits, OpenFile Report 2008-1321, U.S. Department of the Interior, U.S. Geological Survey, p 62.

4. Liu, Z., Shao, Y., Zhou, H., Liu. N., Huang, K., Liu, Q., Zhang, J., Cheng, W., (2018) Major and Trace Element Geochemistry of Pyrite and Pyrrhotite from Stratiform and Lamellar Orebodies: Implications for the Ore Genesis of the Dongguashan Copper (Gold) Deposit, Eastern China, Minerals 8(9): 380, p20.

5. Öhlander, B., Chatwin, T. and Alakangas, L., (2012) Management of Sulfide-Bearing Waste, a Challenge for the Mining Industry, MDPI Minerals 2012, 2, p. 1-10; doi:10.3390/min 2010001 .

6. Seward, T. M., Williams-Jones, A. E., Migdisov, A. (2013) The Chemistry of Metal Transport and Deposition by Ore-Forming Hydrothermal Fluids TM Seward, In book: Treatise on Geochemistry, Chapter: Volume 13: Geochemistry of Mineral Deposits, Publisher: Elsevier Ltd., Editors: Heinrich Holland and Karl Turekian. p. 29-50.

7. Simić, V. (1951) Istorijski razvoj našeg rudarstva, 1951. Izdavačko-štamparsko preduzeće Saveta za Energetiku i ekstraktivnu industriju Vlade FNRJ.

8. Stojanovic, N. J., Radosavljević-Mihajlović, S. A., Radosavljević, A. S., Vuković, S. N., Pačevski, M. A. (2016) Mineralogy and genetic characteristics of the Rudnik $\mathrm{Pb}-\mathrm{Zn} / \mathrm{Cu}, \mathrm{Ag}, \mathrm{Bi}, \mathrm{W}$ polymetallic deposit (Central Serbia) - New occurrence of $\mathrm{Pb}(\mathrm{Ag}) \mathrm{Bi}$ sulfosalts, In Periodico di Mineralogia (2016) 85, An International Journal of Mineralogy, Crystallography, Geochemistry, Petrology, Volcanology and applied topics on Environment, Archaeometry and Cultural Heritage. p 122-123.

9. Vakanjac, B. (2000) Uporedna proučavanja tipomorfnih paragenetskih odnosa u pojedinim ležištima bakra borske rudne zone, Doktorska disertacija, Univerzitet u Beogradu, Rudarsko-geološki fakultet, p. 90-102.

10. https://bitbucket.org/sas_team/sas.planet.bin/downloads/

11. http://www.contangorudnik.co.rs/sr/o-kompaniji-2/istorija

12. https://ec.europa.eu/growth/industry/sustainability/ circular-economy_en

13. https://www.sosbluewaters.org/EPAamd Acid Mine Drainage Prediction

14. https://www.sciencedirect.com/topics/chemistry/pyrite

15. http://webmineral.com/data/Pyrhotite.shtml\#.XYp1Si4zbmg

16. http://webmineral.com/data/Pyrite.shtml\#.XYp1Bi4zbmg 